\author{
Marta Paleczna (D) \\ Uniwersytet Jagielloński w Krakowie \\ marta.paleczna@doctoral.uj.edu.pl
}

\title{
Słownictwo obozowe w przekładzie ustnym na terenie Państwowego Muzeum Auschwitz-Birkenau w opiniach tłumaczy i hiszpańskojęzycznych zwiedzających
}

\section{Wstęp}

Jedną ze zmian widocznych w XXI wieku w badaniach nad przekładem ustnym jest, zdaniem Daniela Gile [2017], zmniejszenie dysproporcji między badaniami poświęconymi przekładowi konferencyjnemu a badaniami poświęconymi innym odmianom tłumaczenia ustnego. Jednak, chociaż rośnie liczba publikacji dotyczących przekładu ustnego na potrzeby służby zdrowia, instytucji sądowych czy w strefach konfliktu [por. Pöchhacker 2015], w polu zainteresowań badaczy rzadko znajduje się przekład ustny wykonywany na potrzeby sektora turystycznego. Istniejące publikacje pozwalają nieco bliżej przyjrzeć się działalności pośredników językowych podczas wypraw odkrywców [np. Chrobak 2012; Delisle 2015; Baigorri Jalón 2015] czy średniowiecznych podróży pielgrzymów do Ziemi Świętej [Chrobak 2012], brakuje natomiast 
badań i opracowań dotyczących przekładu ustnego wykonywanego obecnie w związku z gwałtownie rozwijającym się międzynarodowym ruchem turystycznym.

Rozwój turystyki masowej sprawia, że z usług thumaczy ustnych coraz częściej korzystają zorganizowane grupy turystów. Pośrednicy językowi potrzebni są zwłaszcza w miejscach najchętniej odwiedzanych przez turystów, w których liczba oficjalnych licencjonowanych przewodników posługujących się danym językiem nie jest wystarczająca, by zaspokoić potrzeby odwiedzających. Zgodnie z danymi zaprezentowanymi przez Światową Organizację Turystyki (UNWTO) ${ }^{1}$, w roku 2000 na świecie odnotowano $674 \mathrm{mln}$ przyjazdów turystycznych, w 2010 roku $956 \mathrm{mln}$, natomiast w 2019 roku $1460 \mathrm{mln}$. Gwałtowny rozwój światowego ruchu turystycznego wiąże się z rosnącym zapotrzebowaniem na usługi świadczone przez pośredników językowych w sektorze turystycznym.

\section{Zwiedzanie Państwowego Muzeum Auschwitz-Birkenau}

W Polsce przykładem szczególnego miejsca, w którym zorganizowana grupa zwiedzających może potrzebować pośrednictwa tłumacza ustnego, jest Państwowe Muzeum Auschwitz-Birkenau (PMA-B). Jak wynika $\mathrm{z}$ danych prezentowanych $\mathrm{w}$ corocznych sprawozdaniach $\mathrm{z}$ działalności PMA-B [Bartyzel i Sawicki 2020: 25], w roku 2016 liczba zwiedzających po raz pierwszy przekroczyła 2 miliony i do roku 2019 stale rosła ${ }^{2}$. W roku 2020 ze względu na pandemię wirusa SARS-CoV-2 liczba zwiedzających wyniosła zaledwie 502600 [Bartyzel i Sawicki 2021: 28].

Wizyta w PMA-B może przybierać formę zwiedzania indywidualnego bądź z przewodnikiem. Zwiedzający indywidualni samodzielnie poruszają się po terenie PMA-B i wybierają, które z dostępnych części chcieliby zobaczyć. Osoby decydujące się na zwiedzanie z przewodnikiem mają do wyboru kilka opcji. Jedną z najczęściej wybieranych jest zwiedzanie grupowe oraz w tzw. turach, trwające około 3,5h. Zwiedzanie to obejmuje dwie części byłego nazistowskiego obozu Auschwitz: Auschwitz I i Auschwitz II Birkenau. Podczas zwiedzania pierwszej części (Auschwitz I) zwiedzający mają możliwość zobaczenia m.in. wystawy głównej oraz

\footnotetext{
1 <https://www.unwto.org/global-and-regional-tourism-performance $>$, dostęp 22.08.2020.

2 W roku 2017 liczba zwiedzających wyniosła 2100 000, w 2018 - 2152000 , w 2019 - 2320000 [Bartyzel i Sawicki 2020: 25].
} 
obiektów poobozowych, natomiast podczas zwiedzania drugiej części (Auschwitz II Birkenau) mogą zobaczyć m.in. baraki więźniarskie, rampę wyładowczą oraz ruiny komory gazowej i krematorium nr II lub III³.

Osobami uprawnionymi do oprowadzania zarówno polsko-, jak i obcojęzycznych zwiedzających po PMA-B są licencjonowani przewodnicy - Edukatorzy, którzy zdali stosowne egzaminy. W 2020 roku liczba Edukatorów wynosiła około 340, a dzięki nim możliwe było zwiedzanie w 22 językach [Bartyzel i Sawicki 2021: 28]. Za pośrednictwem Edukatorów muzeum stara się zaoferować zwiedzającym jak najlepszą merytoryczną opiekę przewodnicką. Edukatorzy corocznie uczestniczą w specjalnie przygotowanych szkoleniach. Ich tematyka dotyczy przede wszystkim historii obozu Auschwitz, Holokaustu i II wojny światowej, ale organizowane są także szkolenia z zakresu filozofii, socjologii czy psychologii ${ }^{4}$.

Podczas oprowadzania po PMA-B Edukatorzy korzystają z przeznaczonego do użytku wewnętrznego konspektu zawierającego najważniejsze zagadnienia, które należy w pierwszej kolejności omówić podczas zwiedzania. Narracja Edukatorów w dużej mierze prowadzona jest zgodnie $z$ tematyką prezentowaną na wystawie. Obecnie wystawa stała składa się z dwóch części: wystawy głównej oraz wystaw narodowych ${ }^{5}$. Podczas standardowego zwiedzania grupowego z Edukatorem zwiedzający mają możliwość zobaczenia wystawy głównej mieszczącej się w wybranych poobozowych blokach na terenie byłego obozu Auschwitz I. W jej skład wchodzą m.in. fotografie dokumentalne, fotokopie dokumentów, modele, rzeźby oraz eksponaty historyczne: ubrania więźniarskie, sprzęty będące wyposażeniem pomieszczeń, w których przebywali więźniowie, czy rzeczy odebrane deportowanym Żydom ${ }^{6}$. Ekspozycja znajdująca się w poszczególnych blokach poświęcona została wybranym aspektom związanym $\mathrm{z}$ funkcjonowaniem byłego nazistowskiego obozu:

- Blok 4. Zagłada

- Blok 5. Dowody rzeczowe

- Blok 6. Życie w obozie

- Blok 7. Warunki mieszkaniowe

- Blok 11. Blok Śmierci.

\footnotetext{
$3<$ http://auschwitz.org/zwiedzanie/przewodnicy/>, dostęp 10.08.2021.

$4<$ http://auschwitz.org/zwiedzanie/szkolenia-przewodnikow/>, dostęp 10.08.2021.

5 Por. tematykę wystaw narodowych na $<$ http://auschwitz.org/zwiedzanie/wystawy-narodowe/>, dostęp 10.08.2021.

$6 \quad<$ http://auschwitz.org/zwiedzanie/wystawa-glowna/>, dostęp 10.08.2021.
} 
Materiał zgromadzony w ramach wystawy głównej dotyczy zarówno funkcjonowania obozu koncentracyjnego, jak i eksterminacyjnego. Dzięki licznym elementom ekspozycji zwiedzanie nabiera charakteru audiowizualnego. Edukatorzy, objaśniając poszczególne zagadnienia związane z funkcjonowaniem byłego obozu, mogą odwoływać się do tego, co widzą zwiedzający. Przykładowo, za pomocą znajdującego się na pierwszym piętrze Bloku 4 modelu komory gazowej i krematorium nr II z Birkenau możliwe jest precyzyjniejsze wyjaśnienie i pokazanie zwiedzającym, w jaki sposób funkcjonowały te obiekty. Dodatkowo, pokazując znajdujące się w gablocie grudki ziemi okrzemkowej, łatwiej jest przedstawić działanie Cyklonu B. Jak podaje Minisłownik pojęć z historii Auschwitz znajdujący się na stronie internetowej PMA-B ${ }^{7}$, Cyklon B jest to pestycyd mający formę grudek ziemi okrzemkowej nasączonej cyjanowodorem, który uwalnia się pod wpływem odpowiedniej temperatury i przechodzi w postać gazową.

\section{Przekład ustny wykonywany dla zwiedzających w Państwowym Muzeum Auschwitz-Birkenau}

Pomimo dużej liczby Edukatorów świadczących swoje usługi w PMA-B w przypadku zorganizowanych grup, w wyjątkowych sytuacjach, np. w wysokim sezonie turystycznym czy w przypadku rzadkich języków, liczba ta może nie być wystarczająca.

Grupy zorganizowane, chcąc dokonać rezerwacji zwiedzania, mogą spotkać się z sytuacją braku dostępności Edukatora w interesującym ich języku. Grupa może w takiej sytuacji poprosić o zarezerwowanie Edukatora posiadającego uprawnienia do oprowadzania w języku (najczęściej) polskim, a do PMA-B przyjechać w towarzystwie tłumacza danego języka. Jego znalezieniem i zatrudnieniem zajmuje się grupa czy biuro turystyczne, które organizuje dla niej wyjazd do PMA-B. W konsekwencji podczas zwiedzania grupie towarzyszyć będą dwie osoby: Edukator, który podaje informacje w języku polskim, oraz tłumacz, który przekłada je konsekutywnie na język grupy.

W pierwszej części PMA-B wykorzystywany jest sprzęt audio. Edukator podaje informacje do tłumaczenia, thumacz przekazuje je grupie za pomocą nadajnika z mikrofonem, natomiast zwiedzający wysłuchują ich przy użyciu odbiorników ze słuchawkami. W tej części zwiedzający otrzymują

$7 \quad<$ http://auschwitz.org/media/slownik-pojec/\#Cyklon\%20B>, dostęp 20.08.2021. 
bardzo dużo informacji związanych z funkcjonowaniem zarówno obozu koncentracyjnego, jak i eksterminacyjnego. Grupa przemieszcza się po terenie byłego obozu Auschwitz I po ściśle wyznaczonej trasie. Zwiedzający mają wtedy możliwość zobaczenia wystawy głównej mieszczącej się w wybranych poobozowych blokach oraz oryginalnych bądź częściowo zrekonstruowanych obiektów (m.in. komory gazowej nr I oraz ściany straceń znajdującej się pomiędzy blokami 10 i 11). Podczas thumaczenia wykonywanego w drugiej części PMA-B nie używa się sprzętu audio. Grupa przemieszcza się po rozległym terenie byłego obozu Auschwitz II Birkenau i zatrzymuje w kluczowych miejscach, takich jak np. rampa wyładowcza czy przy ruinach krematorium i komory gazowej nr II lub III. Edukator podaje informacje tłumaczowi, który może przekazać je grupie, dopiero kiedy zwiedzający zbiorą się w jego bliskiej odległości.

Tłumaczenie na terenie PMA-B ma charakter audiowizualny. Tłumacz może odnosić się do tego, co widzą zwiedzający. Dodatkowe ułatwienie stanowi fakt, że tłumaczenie ma charakter powtarzalny. Przy thumaczeniu wykonywanym dla każdej kolejnej grupy tłumacz może lepiej przygotować się do swojej pracy zarówno pod kątem merytorycznym, jak i językowym.

\section{Opis rzeczywistości obozowej i język obozowy}

Były więzień obozu Auschwitz z numerem 9225 Adolf Gawalewicz w swojej pracy Refleksje z poczekalni do gazu: ze wspomnień muzutmana zastawia się ,czy i w jakim stopniu jest w ogóle możliwe podanie zrozumiałej i wiarygodnej opowieści o sprawach niezrozumiałych i niewiarygodnych, które jednak tworzyły rzeczywistość, prawdę tamtego czasu" [Gawalewicz 1968, cyt. za Wesołowska 1996: 11]. Gawalewicz podkreśla, że to, czego świadkami były osoby trafiające do Auschwitz, było niezrozumiałe i niewiarygodne, dlatego też osobom tym często z trudem przychodziło opisanie własnych doświadczeń. W nazistowskich obozach pojawiały się nieznane dotąd obiekty, przedmioty, relacje i wytwory społeczne, które nie miały nazw ani określeń. Najczęściej przybierały one nazwy niemieckie, jako że to Niemcy stworzyli nowe zjawisko - obozy koncentracyjne [Jagoda, Kłodziński et al. 1978: 78]. W obozach tych niemiecki był językiem urzędowym. Więźniowie musieli rozumieć wydawane po niemiecku rozkazy i polecenia, musieli też posługiwać się tymże językiem podczas meldunków, próśb czy pisania listów [Jagoda, Kłodziński et al. 1981: 26]. 
Wśród wielojęzycznej społeczności przebywającej w obozie Auschwitz wykształciła się specyficzna odmiana języka, tzw. lagerszpracha ${ }^{8}$. Odzwierciedlała ona patologiczne warunki życia narzucone przez system obozowy [Jagoda, Kłodziński et al. 1984: 62]. W Słowniku Oświęcimskim została zawarta następująca definicja lagerszprachy:

język obozowy oświęcimski, język lagrowy, lagerszpracha (z niem. die Lagersprache) - oryginalny, osobliwy, oficjalnie nieistniejący z powodu urzędowego w obozie charakteru języka niemieckiego, wynikający z codziennej, koszmarnej, przeciwludzkiej sytuacji zespół konwencji językowych, wulgarny w swej warstwie podstawowej, tworzący system porozumiewania się wielotysięcznej, wielojęzycznej, głównie polskiej i niemieckiej społeczności izolowanej aglomeracji oświęcimskiej, odzwierciedlający doświadczenia jej sztucznego świata koncentracyjnego i praktykę ludobójstwa, wyrażający i porządkujący mnóstwo swoistych dla niego realiów, utrwalający jego skrajnie totalitarny charakter, żywy w środowisku byłych więźniów, dający się rekonstruować na podstawie ich wypowiedzi oraz pisemnych źródeł dokumentacyjnych w skali obejmującej charakterystyczne słownictwo, fonetykę i słowotwórstwo oraz elementy onomastyki [Kłodziński, Masłowski et al.1989: 83].

Obecnie język obozowy jest zjawiskiem historycznym [Jagoda, Kłodziński et al. 1978: 78]. Poznanie rzeczywistości obozowej, jaka wykształciła się w Auschwitz, wymaga jednak zrozumienia języka jej świadków, zwłaszcza - jak zaznaczają Jagoda, Kłodziński i Masłowski - jego bogatego słownictwa [1981: 26]. Język świadków umożliwia opisanie różnych zjawisk związanych z funkcjonowaniem byłego obozu. Przykłady słownictwa pozwalającego określić realia obozowe znaleźć można m.in. w pisemnych wspomnieniach byłych więźniów [np. Nyiszli 1946; Kielar 1966; Birenbaum 1967; Bartnikowski 1969]. Wiesław Kielar, były więzień

8 Do lat 80. język używany przez więźniów w nazistowskich obozach koncentracyjnych nie cieszył się dużym zainteresowaniem badaczy. W latach 40. powstały co prawda pierwsze publikacje, jednak objętościowo były one niewielkie [np. Kuraszkiewicz 1947]. Próby opisania lagerszprachy podjęli się Zenon Jagoda, Stanisław Kłodziński i Jan Masłowski w publikacji Oświęcim nieznany [1981] w rozdziale Krematoryjne esperanto oraz Danuta Wesołowska w publikacji Słowa z piekła rodem. Lagerszpracha [1996]. Najbogatszym zbiorem haseł należących do języka obozowego używanego w byłym obozie Auschwitz jest Słownik Oświęcimski publikowany w częściach na łamach czasopisma Przegląd Lekarski w latach 1978-1991. Jego opracowania podjęli się Zenon Jagoda, Stanisław Kłodziński i Jan Masłowski (później także Danuta Wesołowska). 
obozu Auschwitz z numerem 290, niejednokrotnie w swojej publikacji Anus Mundi [1996/2004] używa słownictwa obozowego:

Zielony kapo przywitał mnie chłodno. Taki stary numer, a taki muzułman? Kogóż mi ten Otto przysłał!? Kapo zdawał się być wyraźnie niezadowolony [1996/2004: 161].

Na rewirze działo się nie najlepiej. Entress robił częste selekcje, skutkiem czego ciężej chorzy szli masowo na szprycę. SDG Klehr, mój „,przyjaciel”, wyżywał się, robiąc dziennie kilkadziesiąt zastrzyków z fenolu. [...] Od pewnego czasu Politische zaczęło się interesować działalnością szpitala, zwłaszcza od momentu, kiedy spostrzeżono, iż ostatnimi czasy zmarło w szpitalu kilku obozowych szpiclów nasłanych na rewir jako funkcyjni bądź chorzy [1996/2004: 171].

Blokowy, chcąc zamaskować swoje zaspanie, był teraz bardzo gorliwy i z przejęciem przewracał sienniki. „Ruscy” mieli paskudny zwyczaj trzymania w swych łóżkach starych szmat, służących im za onuce. Danisz przywołał stubendienstów demonstrując im brudne szmaty; Grapastin kazał sztubowym ćwiczyć „żabki” przez całą długość pieca, tam i z powrotem, aż do upadłego [...]. Odetchnęliśmy z ulgą. Jankiel, zmęczony sportem, ciężko oddychał, ja rozcierałem czerwone od uderzeń policzki [1996/2004: 286].

W publikacji Kielara [1996/2004: 355-361] zawarto również słownik, w którym wyjaśnione zostały najczęściej występujące w niej pojęcia charakterystyczne dla rzeczywistości obozowej, wśród nich m.in. blokowy, buksa, kapo, muzutman, flegmona, szpilowanie, sztuba czy Arbeitskommando, Aufseherin, Durchfal, Lagerfürer. Z kolei na oficjalnej stronie PMA-B dostępny jest Minisłownik pojęć z historii Auschwitz ${ }^{9}$, który zawiera m.in. hasła takie jak cyklon $B$, doty spaleniskowe, karna kompania czy komando. Terminologia ta bardzo często wymaga szerszego objaśnienia nie tylko zwiedzającym obcojęzycznym, ale również polskojęzycznym.

Słownictwo ściśle związane z funkcjonowaniem obozu używane przez Edukatorów podczas oprowadzania w PMA-B pozwala zwiedzającym lepiej zrozumieć rzeczywistość obozową. Jeżeli informacje przewodnickie przekazywane są grupie za pośrednictwem tłumacza, musi on poradzić sobie z przekładem i objaśnieniem tegoż słownictwa.

$9 \quad<$ http://auschwitz.org/media/slownik-pojec/>, dostęp 20.08.2021. 


\section{Wyniki badania}

W latach 2018-2020 został zrealizowany projekt badawczy, którego celem było zebranie informacji dotyczących wybranych kwestii związanych z przekładem ustnym wykonywanym dla zwiedzających na terenie PMA-B. Projekt ten składał się z kilku etapów i obejmował badania przeprowadzone wśród trzech stron uczestniczących w akcie komunikacji, jakim jest wyżej wskazany przekład.

W okresie czerwiec-wrzesień 2018 zostało przeprowadzone badanie wśród tłumaczy wykonujących przekład ustny dla grup odwiedzających PMA-B. Miało ono charakter ankietowy, a kwestionariusz został przygotowany na stronie survio.com. Link do badania został przesłany drogą elektroniczną do kilkunastu tłumaczy wykonujących wskazany przekład oraz udostępniony na grupie małopolskich przewodników lokalnych w mediach społecznościowych (Facebook). W badaniu wzięło udział 30 tłumaczy w wieku 25-54 lat. Zadeklarowali oni staż pracy z grupami turystycznymi od pół roku do ponad 20 lat. Kwestionariusz zawierał ponad 20 pytań dotyczących różnych kwestii związanych z wykonywanym przekładem. Aby poznać opinię tłumaczy na temat trudności przekładu słownictwa obozowego, poproszono respondentów o odpowiedź na następujące pytania: 1. Jakie są charakterystyczne elementy (miejsca, zjawiska, postaci itp.) rzeczywistości obozowej?

2. Czy słownictwo obozowe sprawia duży problem podczas tłumaczenia? Jeżeli tak, proszę podać przykłady.

3. Czy słownictwo specjalistyczne $\mathrm{z}$ innych dziedzin sprawia duży problem podczas tłumaczenia? Jeśli tak, proszę podać, z jakich dziedzin i jakie słownictwo.

4. Czy słownictwo związane z historią i kulturą Polski sprawia problem podczas tłumaczenia (nazwiska, nazwy miejsc, elementy historii itp.)? Jeżeli tak, proszę podać przykłady.

Pytanie dotyczące rzeczywistości obozowej było pytaniem otwartym, natomiast w przypadku trzech kolejnych pytań ankietowani mogli wybrać jedną z odpowiedzi: tak lub nie. Dodatkowo mogli też podzielić się uzupełniającym komentarzem czy podać przykład problematycznego słownictwa. Ankietowanym przypisano numer od 1 do 30 zgodnie z kolejnością wpływania odpowiedzi.

Ankietowani zostali poproszeni o wskazanie tych elementów (miejsc, postaci, zjawisk itp.), które ich zdaniem budują rzeczywistość obozową, 
jako że są to elementy pojawiające się w narracji podczas oprowadzania grup po PMA-B. W poniższej tabeli zostały zawarte elementy wskazane przez respondentów. Odpowiedzi zostały podzielone tematycznie na sześć kategorii: życie codzienne w obozie, budowa obozu, zagłada, więźniowie, załoga obozu i elementy muzeum. Powtarzające się hasła uwzględnione zostały tylko raz.

\begin{tabular}{|l|l|}
\hline $\begin{array}{l}\text { 1. Jakie są charakterystyczne elementy (miejsca, zjawiska, postaci, } \\
\text { przedmioty itp.) rzeczywistości obozowej? }\end{array}$ \\
\hline Życie codzienne w obozie & $\begin{array}{l}\text { choroby, głód, pasiaki, transporty, więźniowie, terror, } \\
\text { baraki mieszalne, areszt, praca, apele, śmierć, kary, } \\
\text { numery, tatuaże }\end{array}$ \\
\hline Budowa obozu & $\begin{array}{l}\text { rozwiązania techniczne (np. drut kolczasty), brama } \\
\text { obozu Auschwitz I z napisem Arbeit Macht Frei, Bra- } \\
\text { ma Śmierci w Auschwitz II Birkenau, ogromna prze- } \\
\text { strzeń w Birkenau, bloki mieszkalne w Auschwitz I, } \\
\text { baraki murowane i drewniane w Auschwitz II } \\
\text { Birkenau, wieże wartownicze, tory, sauna, magazyny, } \\
\text { plac apelowy }\end{array}$ \\
\hline Zagłada & $\begin{array}{l}\text { selekcja, metody zagłady, komory gazowe, krema- } \\
\text { toria, egzekucje, cyklon B, gaz, szubienice, masowa } \\
\text { eksterminacja, Sonderkommando, blok śmierci, } \\
\text { śmierć }\end{array}$ \\
\hline Więźniowie & $\begin{array}{l}\text { Primo Levi, Witold Pilecki, Kazimierz Piechowski } \\
\text { kięźniowie funkcyjni, więźniowie blokowi, straż }\end{array}$ \\
\hline Załoga obozu & $\begin{array}{l}\text { przedmioty odnalezione w obozie (należące do } \\
\text { więźniów i ofiar), makieta krematorium, korytarze } \\
\text { ze zdjęciami ofiar, sale z włosami, butami i waliz- } \\
\text { kami, pozostałości komór gazowych i krematoriów, } \\
\text { fotografie, kominy z cegły, alejki, elementy wystawy, } \\
\text { pomniki, ruiny }\end{array}$ \\
\hline Elementy muzeum & \\
\hline
\end{tabular}

Z uzyskanych informacji wynika, że według ankietowanych na opis rzeczywistości obozowej składają się m.in. kwestie związane $\mathrm{z}$ funkcjonowaniem Auschwitz zarówno jako obozu koncentracyjnego (życie codzienne więźniów), jak i eksterminacyjnego (zagłada). Rzeczywistość tę budują również poszczególne postaci (więźniowie i załoga obozowa) oraz miejsca (budowa obozu). Tematyka omawiana podczas zwiedzania PMA-B jest bardzo rozległa i dotyczy wielu szczegółowych aspektów 
funkcjonowania byłego obozu. Kilku respondentów zwróciło uwagę na eksponaty i obiekty wchodzące w skład PMA-B. Opis rzeczywistości obozowej podczas zwiedzania ułatwia zarówno zabudowa byłego obozu, jak i udostępniona zwiedzającym wystawa.

Pomimo szerokiego zakresu informacji przekazywanych zwiedzającym PMA-B, a w związku z tym rozległej terminologii obozowej, zdecydowana większość ankietowanych uznała, że słownictwo obozowe nie sprawia dużego problemu podczas tłumaczenia. Jedynie trzech ankietowanych przyznało, że słownictwo to może być problematyczne. Ich staż pracy wynosi 2-3 lata.

2. Czy słownictwo obozowe sprawia duży problem podczas tłumaczenia?

\begin{tabular}{|l|l|l|}
\hline Tak & 3 & $10 \%$ \\
\hline Nie & 27 & $90 \%$ \\
\hline
\end{tabular}

Przykłady problematycznego słownictwa obozowego podaje Ankietowany nr 1:

[Problem stanowią] nazwy funkcji więźniów (blokowy, sztubowy etc.), określenia należące do żargonu obozowego,

oraz Ankietowany nr 13:

[Problematyczne słownictwo to na przykład] ziemia okrzemkowa nasycona kwasem pruskim, cyjanowodór.

Według Ankietowanego nr 14 słownictwo obozowe może sprawiać problemy na samym początku:

Duży problem [słownictwo obozowe] sprawia na samym początku, bo nie są to słowa, których używa się w normalnych rozmowach, natomiast po chwili się je już pamięta, dlatego raczej ciężko robi się tłumaczenie, jeśli nie ma się zielonego pojęcia o temacie, z przykładów to: wcielenie Oświęcimia do III Rzeszy, nazwa: więzień funkcyjny, nazwy chorób, stanowiska w obozie, kary itd.

Słownictwo obozowe nie jest więc problematyczne, jeżeli thumacz zapoznał się z odpowiednią terminologią, co potwierdza Ankietowany nr 30:

Jest to kwestia wstępnego opracowania/sprawdzenia kilkudziesięciu specjalistycznych słów, 
oraz Ankietowany nr 29:

[Słownictwo obozowe] nie [sprawia dużego problemu], jeśli tłumacz się przygotuje.

W przypadku trudności w tłumaczeniu terminologii obozowej Ankietowany nr 20 stara się wyjaśniać trudne czy niezrozumiałe pojęcia:

Dużego problemu nie: wyzwaniem raczej są takie pojęcia jak więzień funkcyjny albo apel, plac apelowy, w praktyce nie szukam odpowiedników, a tłumaczę pojęcia: np. plac zgromadzeń służący przeliczeniu stanu więźniów. Problematyczne jest samo sformułowanie „obóz koncentracyjny”, ponieważ nie oddaje tego, co tam było, nie o koncentrację chodziło w KL Auschwitz.

Znajomość słownictwa obozowego pomaga opisać rzeczywistość, z jaką zetknęli się więźniowie. Oprócz słownictwa używanego praktycznie wyłącznie w kontekście obozowym (np. sztubowy), konieczna jest znajomość terminologii specjalistycznej zaczerpniętej z różnych dziedzin. Przykładowo, opisywanie działalności szpitala czy warunków sanitarnych ułatwiają określenia takie jak fenol, pechęrzyca ${ }^{10}$. Przy omawianiu procesu zagłady pomocne mogą okazać się określenia takie jak przepustowość, rampa wyładowcza, bocznica kolejowa, cyklon $B$, doty spaleniskowe czy wskazane powyżej przez jednego $\mathrm{z}$ ankietowanych: ziemia okrzemkowa nasycona kwasem pruskim i cyjanowodó ${ }^{11}$. Z kolei przekazywanie informacji dotyczących warunków życia codziennego może wymagać użycia określeń takich jak latryny, świetliki, brukiew ${ }^{12}$.

\begin{tabular}{|c|c|c|}
\hline \multicolumn{3}{|c|}{$\begin{array}{l}\text { 3. Czy słownictwo specjalistyczne z innych dziedzin sprawia duży problem pod- } \\
\text { czas thumaczenia? }\end{array}$} \\
\hline Tak & 9 & $30 \%$ \\
\hline $\mathrm{Nie}$ & 21 & $70 \%$ \\
\hline
\end{tabular}

Terminologię specjalistyczną z innych dziedzin 9 ankietowanych uznało za problematyczną. W przypadku $8 \mathrm{z}$ nich staż pracy wynosi 2-5 lat, natomiast w przypadku jednego ponad 20 lat. Trudności wynikające $\mathrm{z}$ thumaczenia słownictwa zaczerpniętego z medycyny wskazało czterech ankietowanych, a z chemii - dwóch. Ankietowany nr 18 wskazał również na

\footnotetext{
10 Por. <http://auschwitz.org/historia/szpitale-obozowe/>, dostęp 26.08.2020.

11 Por. $<$ http://auschwitz.org/historia/zaglada/>, dostęp 26.08.2020.

12 Por. $<$ http://auschwitz.org/historia/zycie-w-obozie/>, dostęp 26.08.2020.
} 
trudności w tłumaczeniu słownictwa technicznego. Ponad połowa ankietowanych, która uznała słownictwo specjalistyczne z różnych dziedzin za problematyczne, posiada wykształcenie filologiczne. Oprócz nich, dwóch ankietowanych ukończyło studia na kierunku turystyka, natomiast tylko jeden ukończył studia na kierunku ścisłym (posiada tytuł inżyniera).

Odpowiadając na powyższe pytanie, ankietowani także mogli podzielić się dodatkowym komentarzem. Ankietowany nr 30 zwraca uwagę na fakt, że nieznajomość danego pojęcia nie musi powodować problemów w thumaczeniu, ponieważ

prawie wszystkie pojęcia i zjawiska można wyjaśnić opisowo.

Umieszczenie obozowej narracji w odpowiednim kontekście wymaga dodatkowo użycia terminologii związanej z historią i kulturą Polski. Prowadzenie narracji zwłaszcza na temat okoliczności powstania obozu czy więźniów polskiej narodowości może wymagać wyjaśnienia pojęć takich jak np. rotmistrz, Armia Krajowa, Trzecia Rzesza, Zamojszczyzna, Generalne Gubernatorstwo.

4. Czy słownictwo związane z historią i kulturą Polski sprawia problem podczas tłumaczenia (nazwiska, nazwy miejsc, elementy historii itp.)?

\begin{tabular}{|l|l|l|}
\hline Tak & 4 & $13 \%$ \\
\hline Nie & 26 & $87 \%$ \\
\hline
\end{tabular}

$13 \%$ ankietowanych uznało, że słownictwo związane z historią i kulturą Polski może sprawiać problem podczas przekładu wykonywanego dla zwiedzających PMA-B. W przypadku trzech z nich staż pracy wynosi 2-5 lat, natomiast $\mathrm{w}$ przypadku jednego 10 lat. Trzech z nich ukończyło studia filologiczne, natomiast jeden ukończył szkołę średnią.

Ankietowany nr 30 jako przykład problematycznego słownictwa związanego z historią i kulturą Polski podał:

Rozbiory, nazwy geograficzne (w tym te historyczne, jak np. Prusy czy Austro-Węgry).

Ankietowany nr 29 kolejny raz podkreślił, że terminologia ta nie powinna sprawiać problemów,

jeśli tłumacz się przygotuje. 
Z kolei Ankietowany nr 9 zwrócił uwagę na fakt, że stopień trudności tłumaczenia tejże terminologii zależy również od odbiorcy:

Wszystko zależy od klienta, są ci, którzy nie mają ogólnej wiedzy historycznej, i takim osobom trzeba thumaczyć wszystko ,z grubsza”.

Podsumowując uwagi respondentów na temat słownictwa tłumaczonego podczas zwiedzania PMA-B, należy podkreślić, że zakres tematyczny omawianej wizyty jest bardzo szeroki. Rozległy kontekst, w jakim należy umieścić narrację, sprawia, że oprócz słownictwa ściśle związanego z funkcjonowaniem obozu (nierzadko pojęć, które tam się wykształciły) niezbędna jest znajomość słownictwa $\mathrm{z}$ różnych dziedzin. Pomimo tego, większość ankietowanych uznała, że słownictwo nie stanowi dużego problemu podczas wykonywanego dla zwiedzających thumaczenia. Kilku ankietowanych zwróciło uwagę na fakt, że terminologia obozowa może sprawiać problemy na początku. Oprowadzanie, a więc i tłumaczenie podczas wizyty w PMA-B, ma charakter powtarzalny. Tłumacz z każdym kolejnym tłumaczeniem może coraz lepiej poznawać terminologię, która może być pomocna w objaśnianiu zwiedzającym rzeczywistości obozowej. Natomiast stopień, w jakim należy wyjaśniać konkretne pojęcia, jak sugerował jeden $\mathrm{z}$ ankietowanych, w dużej mierze zależy od grupy odbiorców i ich znajomości kontekstu. Dodatkowo, jak wynika z odpowiedzi udzielonych na pytania związane z innymi aspektami przekładu, zwiedzający starają się niekiedy podpowiedzieć tłumaczowi konkretne wyrażenia czy słowa, jeżeli widzą, że potrzebuje on pomocy w tym zakresie.

W okresie od maja do lipca 2019 zostało przeprowadzone kolejne badanie, tym razem wśród odwiedzających PMA-B. W badaniu wzięły udział 93 osoby w wieku 18-61 lat. Uczestniczyły one w zwiedzaniu PMA-B, podczas którego informacje przewodnickie przekazywane były za pośrednictwem tłumacza. Podczas każdej z tych wizyt tłumaczenie wykonywane było z języka polskiego na język hiszpański. Po zakończeniu zwiedzania badani zostali poproszeni o wypełnienie ankiety w formie papierowej. Kwestionariusz zawierał 7 pytań związanych ze zwiedzaniem PMA-B. W celu poznania opinii zwiedzających na temat słownictwa przekazanego za pośrednictwem tłumacza kwestionariusz zawierał następujące pytania:

1. Czy treści przekazywane przez tłumacza były jasne?

2. Czy pojawiły się słowa/wyrażenia, które powinny zostać wyjaśnione bardziej szczegółowo? 
3. Czy słowa związane z życiem obozowym/ rzeczywistością obozową zostały wystarczająco wyjaśnione?

W każdym z pytań ankietowani mogli wybrać jedną z odpowiedzi: tak lub nie. Dodatkowo mogli podać konkretne przykłady czy podzielić się uzupełniającym komentarzem. Ankietowanym przypisano numery od 1 do 93, zgodnie z kolejnością oddawania kwestionariuszy.

1. ¿Las explicaciones proporcionadas por el intérprete eran claras? (Czy treści przekazywane przez tlumacza byly jasne?)

\begin{tabular}{|l|l|l|}
\hline Sí (Tak) & 91 & $98 \%$ \\
\hline No (Nie) & 2 & $2 \%$ \\
\hline
\end{tabular}

Zwiedzającym, którzy wzięli udział w badaniu, informacje przewodnickie zostały przekazane za pośrednictwem tłumacza. Prawie wszyscy ankietowani uznali, że informacje, które otrzymali, były podane w sposób jasny.

Kilku ankietowanych, którzy wskazali odpowiedź pozytywną, podzieliło się również dodatkowym komentarzem. Ankietowany nr 67 podkreśla, że informacje zostały przekazane rzetelnie:

Nos informan de hechos reales ocurridos con nombres reales. (Dowiedzieliśmy się o wydarzeniach, jasno nazwanych, które naprawdę miały miejsce).

Z kolei Ankietowany nr 37 zwraca uwagę na szeroki zakres przedstawianych informacji:

Apresentou dados e fatos e demostrou muito conhecimento. ([Przewodnik/ thumacz] przedstawił/a dane i fakty oraz wykazał/a się dużą wiedzą).

Podobne doświadczenie opisuje Ankietowany nr 36:

Demonstrou muito conhecimento histórico ([Przewodnik/tłumacz] wykazał/a się dużą wiedzą historyczną).

Ankietowany nr 2 zwrócił uwagę na poprawność gramatyczną wypowiedzi:

La guía conjugaba bien los verbos y se explicaba muy bien. (Przewodniczka dobrze odmieniała czasowniki i bardzo dobrze objaśniała).

Ankietowany nr $60 \mathrm{w}$ przekazywaniu informacji podkreślił znaczenie materiałów muzealnych, takich jak 
los mapas, las maquetas (mapy, makiety).

Jedynie dwóch ankietowanych uznało, że informacje nie zostały przekazane w sposób jasny - Ankietowany nr 8:

Esperaba más detalles. (Oczekiwałam/em więcej szczegółów), oraz Ankietowany nr 7:

Muy ajustado libreto (nada interesante). (Bardzo ograniczone informacje (nic ciekawego)).

\begin{tabular}{|c|c|c|}
\hline \multicolumn{3}{|c|}{$\begin{array}{l}\text { 2. ¿Había algunas palabras/expresiones que deberían explicarse con más de- } \\
\text { talle? (Czy pojawily się słowa/wyrażenia, które powinny zostać wyjaśnione } \\
\text { bardziej szczegółowo?) }\end{array}$} \\
\hline $\begin{array}{l}\text { Sí (Tak) } \\
\end{array}$ & 4 & $4 \%$ \\
\hline No (Nie) & 88 & $95 \%$ \\
\hline
\end{tabular}

Jeden $\mathrm{z}$ ankietowanych nie udzielił żadnej odpowiedzi na to pytanie. 88 ankietowanych uznało, że podczas zwiedzania nie pojawiały się konkretne słowa czy wyrażenia, które powinny zostać wyjaśnione bardziej szczegółowo. Dla 4 ankietowanych wyjaśnienia nie były wystarczające. Ankietowany nr 6 oczekuje rozwinięcia poruszanych kwestii:

Se tendría que alargar más todas las explicaciones sobre los „presos”. (Należałoby rozwinąć wszystkie informacje dotyczące „więźniów”).

Problematyczne mogą okazać się nazwy własne, zwłaszcza imiona i nazwiska. Czasami mogą być one trudne do wychwycenia i zrozumienia, zwłaszcza w przypadku języka polskiego, na co zwraca uwagę Ankietowany $\mathrm{nr} 88$ :

Por favor los nombres polacos un poco más lento. (Proszę, imiona i nazwiska polskie trochę wolniej).

Ankietowany nr 72 pozostawił pozytywny komentarz, w którym podkreśla umiejętności przewodnika (tłumacza):

La guía ha sido muy eficiente. (Przewodniczka była bardzo efektywna). 


\begin{tabular}{|l|l|l|}
\hline $\begin{array}{l}\text { 3. ¿Las palabras relativas a la vida en el campo/a la realidad del campo esta- } \\
\text { ban suficientemente explicadas? (Czy slowa związane z życiem obozowym/ } \\
\text { rzeczywistością obozową zostały wystarczająco wyjaśnione?) }\end{array}$ \\
\hline Sí (Tak) & 90 & $97 \%$ \\
\hline No (Nie) & 3 & $3 \%$ \\
\hline
\end{tabular}

90 ankietowanych uznało, że pojęcia związane z życiem obozowym, z rzeczywistością obozową były wyjaśnione wystarczająco. Ankietowany nr 72 podkreśla, że pojęcia te były wyjaśnione bardzo dobrze:

Sí, muy bien. (Tak, bardzo dobrze).

Ankietowany nr 60 jako przykład pojęcia dobrze wyjaśnionego podaje hasło

Canadá (Kanada),

natomiast Ankietowany $\mathrm{nr} 74$ :

la organización del campo (organizacja obozu).

Trzech ankietowanych przyznało, że pojęcia związane z życiem obozowym, z rzeczywistością obozową nie zostały wyjaśnione wystarczająco. Ankietowany nr 52 zwraca uwagę na zbytnią powierzchowność wyjaśnień:

Era muy superficial la explicación (Bardzo powierzchowne wyjaśnienia).

Podobne zarzuty wysuwa Ankietowany nr 7:

Muy ajustado libreto (Bardzo ograniczone informacje).

Ankietowany nr 2, chociaż wskazuje, że poszczególne kwestie zostały dobrze wyjaśnione, zwraca uwagę na zbyt małą liczbę relacji:

Aunque me gustaría saber más relatos. (Chociaż chciałbym usłyszeć więcej relacji).

Podsumowując wypowiedzi ankietowanych, należy podkreślić, że w zdecydowanej większości przypadków informacje podawane przez tłumacza były dla nich jasne i zrozumiałe. Kilku ankietowanych uznało, że informacje, które otrzymali, były niewystarczające i wymagały szerszego wyjaśnienia. Wyniki badania nie pozwalają jednak stwierdzić, dlaczego poszczególni ankietowani uznali, że liczba informacji była niewystarczająca. Ich niezadowolenie mogło wynikać np. z faktu, że tłumacz nie był 
w stanie przełożyć wszystkich informacji podawanych przez Edukatora bądź też liczba informacji przekazywanych przez Edukatora nie spełniła ich oczekiwań. Należy zwrócić również uwagę na fakt, że czas zwiedzania PMA-B jest ściśle ograniczony, a dodatkowo duża liczba zwiedzających może sprawiać, że czas przeznaczony na przekazywanie informacji w rzeczywistości ulega skróceniu.

\section{Podsumowanie}

Tłumaczenie ustne wykonywane dla zwiedzających na terenie byłego nazistowskiego obozu Auschwitz wymaga znajomości charakterystycznego słownictwa obozowego. Dzięki niemu możliwa jest narracja pozwalająca w dokładny sposób przedstawić historię obozu oraz wiele aspektów związanych z jego funkcjonowaniem. Większość ankietowanych, zarówno tłumaczy, jak i zwiedzających, uznała, że słownictwo obozowe - dla thumaczy w przekładzie, dla zwiedzających w odbiorze - nie stanowiło problemu. Warto jednak zwrócić uwagę na fakt, że zwiedzający, którzy wzięli udział w badaniu, pochodzili głównie z Hiszpanii, a więc z kraju europejskiego. Być może podobne badanie przeprowadzone wśród zwiedzających np. z Azji ukazałoby inne trudności wynikające z przekładu słownictwa obozowego. Ciekawych spostrzeżeń mogłaby dostarczyć również analiza przekładu omawianej terminologii na podstawie nagrań wykonywanych tłumaczeń (co obecnie nie jest możliwe ze względów formalnych).

Tłumaczenie słownictwa obozowego, w tym specjalistycznego z różnych dziedzin, oraz związanego z historią i kulturą Polski podczas zwiedzania PMA-B dla większości tłumaczy biorących udział w badaniu nie stanowi dużego problemu. Problematyczne sytuacje zdarzają się częściej w przypadku pierwszych tłumaczeń wykonywanych dla zwiedzających na terenie PMA-B. Omawiane thumaczenie ma charakter powtarzalny. Zwiedzający poruszają się po ściśle wytyczonej stałej trasie, dlatego tłumacz może lepiej przygotować się do każdego kolejnego thumaczenia.

Kilkukrotnie zwrócono jednak uwagę na fakt, że słownictwo nie jest problematyczne, jeżeli tłumacz jest przygotowany. Pod względem słownictwa przygotowanie do thumaczenia wykonywanego podczas zwiedzania PMA-B może ułatwiać m.in.:

- bardzo duży wybór literatury dotyczącej funkcjonowania obozu Auschwitz (dostępnej w wielu językach), która pozwala na dogłębne 
zapoznanie się z terminologią niezbędną do opisu rzeczywistości obozowej (nawet w najłatwiej dostępnej internetowej encyklopedii, Wikipedii, hasło Auschwitz-Birkenau zostało omówione w ponad 80 językach),

- kontakt z Edukatorami, którzy zajmują się oprowadzaniem zwiedzających w danym języku i którzy dzięki swojemu doświadczeniu mogą służyć pomocą.

Dodatkowe ułatwienie stanowi forma zwiedzania:

- powtarzalny charakter zwiedzania, dzięki któremu tłumacz może coraz lepiej przygotować się do każdej kolejnej wizyty w PMA-B pod względem merytorycznym i językowym,

- audiowizualny charakter zwiedzania, dzięki któremu tłumacz może pokazać to, co stara się wyjaśnić w danym momencie.

Kilku zwiedzających biorących udział w badaniu przyznało, że informacje, które otrzymali oni podczas zwiedzania, nie były wystarczające. Ich komentarze nie odnosiły się jednak do tego, że konkretne pojęcia nie były odpowiednio wyjaśnione, ale do tego, że spodziewali się oni otrzymać więcej informacji dotyczących danych zagadnień. Problemu nie stanowiło dla nich niezrozumienie konkretnych pojęć, a raczej chęć dowiedzenia się więcej (np. usłyszenia większej liczby relacji więźniów). Podczas zwiedzania PMA-B zarówno Edukator, jak i tłumacz muszą przestrzegać zasad poruszania się po terenie byłego obozu. Jednym z najbardziej restrykcyjnych ograniczeń jest ściśle określony czas zwiedzania. Osoby prowadzące narrację muszą bardzo starannie dobierać przekazywane treści, by ich komentarz pozostał jasny i spójny, ale by mieścił się w przewidzianym dla grupy czasie. W zależności od poziomu wiedzy zwiedzających niektóre kwestie mogą wymagać dogłębniejszego wyjaśnienia, co również niekiedy może być utrudnione ze względu na ograniczenie czasowe.

\section{Bibliografia}

Baigorri Jalón, J. (2015), „Spain”, [w:] Franz Pöchhacker, red. Routledge Encyclopedia of Interpreting Studies, Routledge Taylor \& Francis Group, LondonNew York: 393-396.

Bartnikowski, B. (1969/2007), Dzieciństwo w pasiakach, Państwowe Muzeum Auschwitz-Birkenau, Oświęcim.

Bartyzel, B., Sawicki, P. (2020), Sprawozdanie 2019, Państwowe Muzeum Auschwitz-Birkenau w Oświęcimiu, Oświęcim. 
Bartyzel, B., Sawicki, P. (2021), Sprawozdanie 2020, Państwowe Muzeum Auschwitz-Birkenau w Oświęcimiu, Oświęcim.

Birenbaum, H. (1967/2001), Nadzieja umiera ostatnia, Państwowe Muzeum Auschwitz-Birkenau w Oświęcimiu, Oświęcim.

Chrobak, M. (2012), Między światami. Ttumacz ustny oraz komunikacja międzykulturowa w literaturze odkrycia i konkwisty Ameryki, Wydawnictwo Uniwersytetu Jagiellońskiego, Kraków.

Delisle, J. (2015), „Canada”, [w:] Franz Pöchhacker, red. Routledge Encyclopedia of Interpreting Studies, Routledge Taylor \& Francis Group, London-New York: 40-45.

Gawalewicz, A. (1968), Refleksje z poczekalni do gazu: ze wspomnień muzutmana, Państwowe Muzeum Auschwitz-Birkenau w Oświęcimiu, Oświęcim.

Gile, D. (2017), „Traditions and Innovation in Interpreting Studies: a Personal Analysis for 2016”, Domínios de Lingu@gem. 11(5): 1424-1439, https://doi. org/10.14393/DL32-v11n5a2017-2.

Jagoda, Z., Kłodziński, S., Masłowski, J. (1978), Stownik oświęcimski. A-B. (Makieta). Przeglad Lekarski. 35(1): 78-94.

Jagoda, Z., Kłodziński, S., Masłowski, J. (1981), Oświęcim nieznany, Wydawnictwo Literackie, Kraków.

Jagoda, Z., Kłodziński, S., Masłowski, J., Wesołowska, D. (1984), Słownik oświęcimski (C-Ć). (Makieta). Przegląd Lekarski. 41(1): 62-67.

Kielar, W. (1996/2004), Anus Mundi, Atut, Wrocław.

Kłodziński, S., Masłowski, J., Wesołowska, D. (1989), Słownik oświęcimski (I-J). (Makieta). Przeglad Lekarski. 46 (1): 66-85.

Kuraszkiewicz, W. (1947), Język polski w obozie koncentracyjnym, Towarzystwo Naukowe K.U.L., Lublin.

Nyiszli, M. (1946/2000), Bytem asystentem doktora Mengele (tłum. Tadeusz Olszański), Frap-Books, Oświęcim.

Pöchhacker, F. (red.) (2015), Routledge Encyclopedia of Interpreting Studies, Routledge Taylor \& Francis Group, London-New York.

Wesołowska, D. (1996), Słowa z piekieł rodem: lagerszpracha, Impuls, Kraków. https://www.unwto.org/global-and-regional-tourism-performance http://auschwitz.org/zwiedzanie/przewodnicy/ http://auschwitz.org/zwiedzanie/szkolenia-przewodnikow/ http://auschwitz.org/zwiedzanie/wystawa-glowna/ http://auschwitz.org/zwiedzanie/wystawy-narodowe/ http://auschwitz.org/media/slownik-pojec/\#Cyklon\%20B http://auschwitz.org/media/slownik-pojec/ 
http://auschwitz.org/historia/szpitale-obozowe/

http://auschwitz.org/historia/zaglada/

http://auschwitz.org/historia/zycie-w-obozie/

\begin{abstract}
Abstrakt
W artykule przedstawiono część wyników uzyskanych w ramach kilkuetapowego projektu badawczego, który został zrealizowany w latach 20182020. Jego celem było zebranie informacji dotyczących przekładu ustnego wykonywanego dla zwiedzających na terenie Państwowego Muzeum Auschwitz-Birkenau (PMA-B). Omówiona została kwestia trudności przekładu słownictwa obozowego podczas wykonywania wyżej wskazanego tłumaczenia. Swoimi opiniami podzieliło się 30 tłumaczy ustnych wykonujących omawiany przekład oraz 96 zwiedzających, którym informacje przewodnickie zostały przekazane za pośrednictwem thumacza w języku hiszpańskim.
\end{abstract}

Słowa kluczowe: przekład ustny, słownictwo obozowe, Państwowe Muzeum Auschwitz-Birkenau

\begin{abstract}
Nazi Concentration Camp Vocabulary in Oral Interpreting in the Auschwitz-Birkenau State Museum in the Opinion of Interpreters and Spanish-Speaking Visitors

The article presents some of the results obtained as part of multi-stage research project that was carried out in 2018-2020. Its purpose was to collect information on interpreting performed for visitors at the Auschwitz-Birkenau State Museum. The article discusses the difficulty of translating the camp vocabulary when performing the above-mentioned interpreting. Thirty interpreters shared their views on the oral translation as well as 96 visitors, for whom the information during the tour was provided by a Spanish speaking interpreter.
\end{abstract}

Keywords: interpreting, Nazi concentration camp vocabulary, the Auschwitz-Birkenau State Museum 